九州大学学術情報リポジトリ

Kyushu University Institutional Repository

\title{
Structural Changes and Sustainable Development of Traditional Handicraft Villages in the Kinh Bac Area, Northern Veitnam
}

\section{Tsuji, Kazunari}

Laboratory of Farm Management, Division of International Resource Economics and Business Administration, Department of Agricultural and Resources Econoimcs, Faculty of Agriculture, Kyushu University

Dinh Pham, Van

Faculty of Economics and Rural Development, Hanoi Agricultural University

https://doi.org/10.5109/24473

出版情報 : 九州大学大学院農学研究院紀要. 47 (1)，pp. 205-219，2002-10-30. Kyushu University バージョン：

権利関係 : 


\title{
Structural Changes and Sustainable Development of Traditional Handicraft Villages in the Kinh Bac Area, Northern Vietnam
}

\author{
Kazunari TSUJI and Dinh PHAM Van* \\ Laboratory of Farm Management, Division of International Resource Economics and \\ Business Administration, Department of Agricultural and Resource Economics, \\ Faculty of Agriculture, Kyushu University, Fukuoka, 812-8581, Japan. \\ (Received June 11, 2002 and accepted June 21, 2002)
}

\begin{abstract}
The purpose of this paper is to explicate the current developments of rural traditional handicraft industries and structural changes in the handicraft villages of northern Vietnam. Rural industrialization is needed for creating job opportunities and increasing income of the abundant rural people as well as agricultural development in Vietnam. For such rural industrialization, the Red River Delta, Kinh Bac, has the advantages of historically holding kinds of labor-intensive and unique traditional handicraft business. Since the beginning of economic renovation in 1986, along with enlargement of market, some handicraft villages have quickly developed.

In this paper, some positive and negative impacts of the development of traditional handicraft sector on the household economy, regional agriculture and rural society were analyzed by the result of field survey conducted in 1999.
\end{abstract}

\section{INTRODUCTION}

In the Red River Delta, which is one of the most densely populated areas in the world and its population still now has been increasing with about two percents of annual growth rate, the employment of rural people is one of the most serious problems to be settled. Intensification and diversification of agriculture must be a solution to this problem. However, it is absolutely impossible for the only agricultural sector to make full use of the abundant rural laborer in this area and offer them enough income for their living. Therefore, the appropriate rural industrial development is necessary in this area (Cho, 2000). In our idea, rural industrialization should be carried out by not introducing enormous modern industries but encouraging the existing labor-intensive traditional handicraft industries, because small-scale industrialization must harmonize with the regional agricultural development and stabilization of rural society and economy.

The ancient land of Kinh Bac, which stands for the north of Hanoi capital, comprises many traditional handicraft villages ${ }^{1}$ in Bac Ninh, Bac Giang, and Hanoi provinces in the Red River Delta. Since Vietnamese ancestors, who were artisans and talented workers, came there to start producing their excellent handicraft products in the early last century,

\footnotetext{
*Assoc. professor, Dean of Faculty of Economics and Rural Development, Hanoi Agricultural University, Vietnam A JICA participant of HAU-JICA ERCB project

1 For example, the following handicraft products are especially well-known: woody crafts in Huong Mac, Dong Ky; fork-painting in Dong Ho; silver and metal works in Dai Bai, Dang Sam; glazed ceramics in Bat Trang; silk in Tuong Giang, Van Phuc; inlaid shell and lacquer paintings in Dinh Bang; leather products in Kieu Ky; medical herbs in Ninh Hiep.
} 
the descendants have maintained and developed their production skills and techniques for a business. And, at present, this area has become famous for many kinds of traditional handicraft products supplied by plenty of small-scale farm households engaged in both handicraft business and agriculture.

Recently, especially since the economic renovation in 1986, the development of traditional handicraft production has made a positive contribution to the structural change of rural economy and also to the employment in rural areas in the Red River Delta. However, those traditional handicraft villages are also facing to some critical constraints for the further development of their business in the future as follows:

(1) Severe competition between their traditional handicraft products and industrial products;

(2) Necessity of modern equipment and technology for higher productivity and quality of the products with lower production cost;

(3) Conflict between the maintenance and the mass production of traditional handicraft products;

(4) Reconsideration of the "family secrets", which means an unique production method for traditional handicrafts that has been kept and handed down from generation to generation in each household;

(5) Sustainable procurement of scare raw materials;

(6) Treatment of environmental damages caused by haphazard development.

Besides, more attention should be paid to the two following problems concerning regional agricultural development such as:

(1) Negative impact on income disparity between non--farm activity and farming activity;

(2) Care for the structural changes of regional agriculture caused by a rapid development of traditional handicraft industry.

In order to examine practical situations in handicraft villages as mentioned above, our research group conducted a scientific investigation. And our attention was mainly focused on the three following subjects:

(1) To assess the actual situation of small-scale farm households in creating job opportunities and increasing income for themselves in handicraft villages;

(2) To make clear the trials for improving the efficiency of the handicraft business by producers themselves and local authorities;

(3) To find out the impacts on agricultural activity by the development of handicraft enterprises in both levels of household and region.

\section{RESEARCH SITES}

For this research, four typical traditional handicraft villages, namely Bat Trang, Dai Bai, Ninh Hiep, and Long Van, were selected as the research sites depending on the differences in characteristics of products, size and intensity of the business, stage and speed of industrial development.

The product of Bat Trang, Dai Bai, Ninh Hiep, and Long Van are ceramics and pottery, brass-works, herb medicine, and incense stick, respectively. The characteristics in producing each product can be explained as follows: the production process of ceramics and brass-works includes both skilled and simple works to be labor receptive; the 
production of herb medicine requires highly professional knowledge of products; the processing of incense stick depends on only simple hand work. Judging from the characteristics of the production process, it might be expected that ceramics and brass-works are apt to receive the benefit by industrial development with modern equipment and techniques for the production in comparison with the two latter products. That is a factor to affect the speed of industrial development in handicraft production as well as the market demand.

\section{RESULTS}

\section{Socio-economic characteristics of the surveyed villages Location}

Table 1 shows some socio-economic situations of these villages. These villages stand at the distance of only $12-32 \mathrm{~km}$ far from Hanoi city with more than 2.5 millions of population, which is main market for their products. This is a very favorable factor for the handicraft villages to develop rapidly, especially after starting transformation of the economic system. Thus, they have been able to enjoy necessary labor force and market of the products for their handicraft--business development.

\section{Land resources and land use}

The natural land resource of these villages is $100-500$ ha, which is common size among the rural villages in the Red River Delta. The size of agricultural land, however, has been diversified village by village gradually. Bat Trang is a special case with only nine ha of cultivated land remained. The most agricultural land there has been diverted for residential or handicraft production site. In a result, the regional agriculture in Bat Trang is going to disappear. This problem will be discussed later again.

\section{Household}

The total number of households in these villages is $300-2,300$. This number is also common as the villages of the Red River Delta. The total number of households engaged in handicraft production is 667 in Bat Trang, 700 in Dai Bai, 410 in Ninh Hiep, and 20 in Long Van, accounting for $41 \%, 64 \%, 18 \%$ and $6 \%$ to the total number of households in each village, respectively. Generally, in the case of these handicraft villages those can create kinds of incidental job opportunities, the total number of households has been increasing by cadets and immigrations into the villages. However, the number of handicraft production households has been quite stable because of the necessity of dexterity and the existence of "family secret".

\section{Population and labor recourse}

Total population of the surveyed villages was 1,500-13,000 and extremely high population density was observed in Bat Trang and Ninh Hiep with nearly 6,000 person $/ \mathrm{km}^{2}$

2 For example, it is still now common that a father hands over his unique processing knowledge and procedure of traditional medicine to only one child who is selected from his children in Ninh Hiep. This situation is more or less same in other handicraft villages (Hien, 2000). 
and 2,650 person $/ \mathrm{km}^{2}$ respectively. The percentage of the number of people engaged in handicraft production to the total population was 37\% in Bat Trang, 39\% in Dai Bai, and $6 \%$ in Long Van. And, in the case of Bat Trang and Dai Bai, if including the villagers engaged in allied occupations such as transportation of materials and products, and sale of products, its ratio might be well over $70 \%$ of total workers. It is clear that the regional economy of those villages highly depends on its traditional handicraft business.

\section{Infrastructure}

In general, infrastructures in these villages were also well developed. Especially, the well-maintained village road covered with asphalt or concrete is very useful to transport heavy materials and frail products. And, electric power station also has been established in these villages besides Long Van to supply enough electric power for the handicraft productions and the daily life of villagers.

Table 1. Socio-economic status of the surveyed handicraft villages

\begin{tabular}{|c|c|c|c|c|c|}
\hline & Unit & Bat Trang & Dai Bai & Ninh Hiep & Long Van \\
\hline \multicolumn{6}{|l|}{ 1. Distance from } \\
\hline - Hanoi & $\mathrm{km}$ & 12 & 30 & 15 & 32 \\
\hline - District capital & $\mathrm{km}$ & 12 & 15 & 15 & 10 \\
\hline - Nearest townlet & $\mathrm{km}$ & 3 & 5 & 4 & 6 \\
\hline \multicolumn{6}{|l|}{ 2. Land resource } \\
\hline - Natural land & ha & 107 & 383 & 489 & 110 \\
\hline - Agricultural land & ha & 9 & 260 & 357 & 72 \\
\hline \multicolumn{6}{|l|}{ 3. Households } \\
\hline - Total number of households & household & 1,628 & 1,100 & 2,294 & 332 \\
\hline $\begin{array}{l}\text { - Number of traditional } \\
\text { handicraft households }\end{array}$ & household & 667 & 700 & 410 & 20 \\
\hline $\begin{array}{l}\text { - Ratio of traditional handicraft } \\
\text { households }\end{array}$ & $\%$ & 41.0 & 63.6 & 17.9 & 6.0 \\
\hline \multicolumn{6}{|l|}{ 4. Population } \\
\hline - Total number of residents & Person & 6,252 & 5,600 & 12,935 & 1,500 \\
\hline - Population density & $\mathrm{p} . / \mathrm{km}^{2}$ & 5,843 & 1,461 & 2,645 & 1,355 \\
\hline $\begin{array}{l}\text { Number of workers engaged in } \\
\text { traditional handicraft }\end{array}$ & Person & 2,300 & 2,200 & - & - \\
\hline $\begin{array}{l}\text { Ratio of handicraft workers for } \\
\text { the total residents }\end{array}$ & $\%$ & 36.8 & 39.3 & - & 6.0 \\
\hline \multicolumn{6}{|l|}{ 5. Infrastructure } \\
\hline $\begin{array}{l}\text { - Road paved with asphalt or } \\
\text { concrete }\end{array}$ & $\mathrm{km}$ & 5 & 2 & 10 & 1 \\
\hline - Non-paved road & $\mathrm{km}$ & 5 & 1 & 8 & 3 \\
\hline - Water way & $\mathrm{km}$ & 1 & 2 & 5 & 0 \\
\hline - Electric power station & site & 1 & 2 & 2 & 0 \\
\hline
\end{tabular}

Source: Commune offices 


\section{Characteristics of the handicraft production households in the surveyed villages}

In this section, on the basis of interview with 150 households in total, the business and economic performances of handicraft production household in the four villages are examined.

\section{Enterprise structure of the handicraft households}

Table 2 indicates the structural characteristics of the surveyed households from four different angles. First, for the business structure of the households, there were no handicraft households engaged in agriculture in Bat Trang but the households in other three villages engaged in mainly two business sectors of handicraft production and agriculture. Secondly, observing the handicraft production process to be operated, the most of households engaged in whole process of handicraft production with only little divergence of the production process among handicraft household. This fact suggests the strong autonomy of each handicraft household ${ }^{3}$. Thirdly, the form of business organization of handicraft households was mainly individual family enterprise. Recently, although another forms of business organization such as limited company and joint enterprise have developed in Bat Trang, Dai Bai, and Ninh Hiep, those ratios were still not so high so far as our interview concerned. In our understanding, however, it is thought that such new types of business organization will increase to enlarge the size of capital and win their

Table 2. Characteristics of surveyed handicraft households

(Unit: \%)

\begin{tabular}{lrrrr} 
& Bat Trang & Dai Bai & Ninh Hiep & Long Van \\
\hline 1. Business structure of handicraft households & & & & \\
- Specialized in handicraft production & 81.1 & 10.5 & 3.7 & 0.0 \\
- Cum agriculture & 0.0 & 78.9 & 88.1 & 100.0 \\
- Cum services & 18.9 & 2.6 & 3.7 & 0.0 \\
- Cum agriculture and services & 0.0 & 7.9 & 3.7 & 0.0 \\
\hline 2. Production process of households engaged in & & & & \\
- Overall & 100.0 & 86.5 & 87.8 & 100.0 \\
- Partly & 0.0 & 13.5 & 12.2 & 0.0 \\
\hline 3. Type of business organization & & & & \\
- Limited company & 5.3 & 0.0 & 0.0 & 0.0 \\
- Joint enterprise & 7.9 & 7.5 & 3.8 & 0.0 \\
- Individual family enterprise & 86.9 & 92.5 & 96.2 & 100.0 \\
\hline 4. Experience of handicraft production & & & & 100.0 \\
- Heredity & 94.4 & 97.4 & 100.0 & 0.0 \\
\hline
\end{tabular}

Source: Survey, 1999.

3 Such situation has been gradually changing in Bat Trang. Some small-scale handicraft households start charging a big company that holds high skill and laborsaving machinery with an important part of production process such as material preparation (Mai, 2000). 
business competition in some fields of handicraft production such as ceramics production or brass works. Fourthly, pointing out the experience of handicraft production, most of the surveyed households took over the handicraft business from previous generation and only a few founders started their business in Bat Trang and Dai Bai. This fact shows that the handicraft business in Kinh Bac still strongly maintains the family tradition. In short, the movement of Bat Trang or Dai Bai suggests us that the sustainability of family tradition might vary according to the differences in the kind of handicraft product, the size and development stage of industrialization in handicraft production, and the modernization in each village.

\section{Land resource of the handicraft households}

Table 3 shows the land resource that the surveyed handicraft households hold and operate. The gross plottage area for handicraft production was, on average, $405 \mathrm{~m}^{2}$ in Bat Trang, $93 \mathrm{~m}^{2}$ in Dai Bai, $23 \mathrm{~m}^{2}$ in Ninh Hiep, and $28 \mathrm{~m}^{2}$ in Long Van, respectively. Generally, the land size for handicraft production is small, even the case of Bat Trang as this fact indicates. Actually, The traditional herb medicine in Ninh Hiep and incense stick in Lang Van was produced just in the garden of households.

It is considered, however, that the production size is gradually diversifying in Bat Trang, Dai Bai, and Ninh Hiep. The largest plottage of surveyed household in those villages was $3,000 \mathrm{~m}^{2}$ in Bat Trang, $1,200 \mathrm{~m}^{2}$ in Dai Bai, and $540 \mathrm{~m}^{2}$ in Ninh Hiep and those were 7 times, 13 times, and 23 times as much as of average size of production site in each village, respectively. Such handicraft households expanding their production area depended on land lease from outsides. In fact, according to a result of our interview, the greater part of total leasing land area of the surveyed handicraft household was rented in by a few big-size handicraft production households with the largest size of $3,000 \mathrm{~m}^{2}$ in Bat Trang, $700 \mathrm{~m}^{2}$ in Dai Bai, and 1,080 $\mathrm{m}^{2}$ in Ninh Hiep, respectively.

Table 3. Land size for the handicraft production at surveyed households

\begin{tabular}{lcrrr}
\hline & & & & $\left(\text { Unit: }^{2}\right)^{\prime}$ \\
\hline 1. Plottage for the handicraft production & Bat Trang & Dai Bai & Ninh Hiep & Long Van \\
- Largest plottage & 405 & 93 & 23 & 28 \\
2. Land lease & 3,000 & 1,200 & 540 & 50 \\
- Total leasing area & & & & \\
- Average & 4,445 & 2,375 & 1,620 & 0 \\
- Largest unit & 117 & 59 & 30 & 0 \\
\hline
\end{tabular}

Source: same as Table 2

\section{Labor resources of the handicraft households}

Table 4 gives us some information on labor force in the surveyed handicraft household. The number of family labors engaged in their own handicraft production was 73 people in Bat Trang, 11 in Dai Bai, 31 in Ninh Hiep and 18 in Long Vang. And, the number of employees was 431 people in Bat Trang, 123 in Dai Bai, 182 in Ninh Hiep, and 
no employees in Long Van. Quite great numbers of workers were employed for family labors except Long Van.

Looking at the number of workers by their production skill and technique level, most of handicraft householders have been certified as main worker and only four family workers have received the certificate of master in each Bat Trang and Dai Bai". As far as this fact shows, handicraft householders seem to be satisfied with their current status and not so much interested in upgrading their own production skill or technique for master. Its reasons would vary village by village. First, the householders in Bat Trang and Dai Bai prefer to hire excellent workers who have high production technique and knowledge with reasonable salary. Especially, its remarkable tendency was observed in Dai Bai where the number of family workers was only 11 people, and they seem to be going to become not workers but managers. Secondly, the householders in Ninh Hiep have unique professional and original knowledge about medicine production that no one can imitate, so that they do not care about any titles of their skill. As their concern is to keep "family secret" firmly, only a few skilled workers were employed except many assistant workers who engage in simple works. Thirdly, in Long Van, their handicraft business is much simpler than the others are and no better than supplemental job of farm households. Therefore, the householders care nothing for higher skill level and hired workers.

By the way, although Table 4 did not show us it, the ratio of female laborers to the total number of laborers was rather high and came up to $40.9 \%$ on average of all surveyed households. In the case of Bat Trang, the ratio reached to $46.7 \%$. Female workers who have less chance to get another job were attracted into hard work in unfavorable and terrible conditions such as kiln entrance in Bat Trang, metal lamination in Dai Bai etc".

Table 4. Number of workers engaged in handicraft production by skill and technique level

(Unit: person)

\begin{tabular}{llrrrr}
\hline & Bat Trang & Dai Bai & Ninh Hiep & Long Van \\
\hline 1. Family members of surveyed households (total) & 73 & 11 & 31 & 18 \\
- Master & 4 & 4 & 0 & 0 \\
- Main worker & 51 & 3 & 29 & 18 \\
- Secondary worker & 2 & 0 & 0 & 0 \\
- Primary worker & 3 & 4 & 2 & 0 \\
- Assistant worker & 13 & 0 & 0 & 0 \\
2. Employees (total) & 431 & 123 & 182 & 0 \\
- Master & 6 & 2 & 3 & 0 \\
- Main worker & 76 & 18 & 5 & 0 \\
- Technical worker & 44 & 5 & 1 & 0 \\
- Assistant worker & 305 & 98 & 172 & 0 \\
- Marketing staff & 0 & 0 & 1 & 0 \\
\hline
\end{tabular}

Source: same as Table 2

4 Workers can be certified such title by finishing advanced training course.

5 For example, the air pollution in Bat Trang is very serious and some kinds of harmful substances over a daily tolerance limit were observed at the recent investigation (Mai, 2000). 


\section{Investment for facilities and machineries for the handicraft production}

Table 5 shows us the investment for manufacturing plant and machinery for handicraft production at the surveyed households. According to this table, we can know the difference in modernization of handicraft production by each surveyed village. First, however more than 10 times of gap between the biggest and the smallest was, the size of workshop building was still not big enough in any village. Secondly, a bigger gap in the amount of investment in manufacturing plant and machinery was recognized. Modern facilities and machineries were mainly introduced in ceramics production of Bat Trang and brass-works production in Dai Bai. And, the producers in Bat Trang attached great importance to the investment for facilities, meanwhile those in Dai Bai put much investment for machineries. Thirdly, however, as judged from the size of largest investment, only a few numbers of big-size companies invested huge amount of money in their plant and machinery. So that, it is afraid that the differential in business size and intensity among handicraft production households is going to enlarge not only among different kinds of handicraft field but also in the same field.

Table 5. Investment in plant and machinery at the handicraft production

(Unit: Million dong)

\begin{tabular}{llcrrc}
\hline & & Bat Trang & Dai Bai & Ninh Hiep & Long Van \\
\hline 1. Workshop building $\left(\mathrm{m}^{2}\right)$ & 246 & 62 & 14 & 23 \\
2. Facility & 63.8 & 6.4 & 0.2 & - \\
- Largest & 520 & 70 & 5 & - \\
3. Machinery & 18.2 & 46.0 & 4.3 & - \\
- Largest & 180 & 1,300 & 367 & - \\
\hline
\end{tabular}

Source: same as Table 2

Comparing the total investment at the present time with the initial capital, on the basis of Table 6 , it is clear that the business size of handicraft households in the three villages besides Long Van has developed. Its growth rate accounts for 2.8 times in Bat Trang, 1.7 times in Dai Bai, and 3.6 times in Ninh Hiep. Meanwhile that in Long Van remained as it had been. Another remarkable fact is that most of their capital increase depended on not loan but equity capital.

Table 6. Average capital investment amount for handicraft production at surveyed households (Unit: Thousand dong/household; \%)

\begin{tabular}{lrrrr}
\hline & Bat Trang & Dai Bai & Ninh Hiep & Long Van \\
\hline 1. Initial capital & 99,111 & 85,100 & 55,936 & 1,401 \\
2. Capital investment at the period of survey & 278,459 & 148,800 & 201,000 & 1,401 \\
- Equity (\%) & 93.1 & 87.6 & 81.6 & 100.0 \\
- Loan (\%) & 6.9 & 12.4 & 18.4 & 0.0 \\
\hline
\end{tabular}

Source: same as Table 2 
On the other hand, however, this fact is also one of the evidences that stable and attractive financial market for the business has not enough developed in rural Vietnam. If adequate rural finance system developed well, the more rapid growth of handicraft business might have realized. Table 7 shows the biggest amount of loan from each donor to unspecific debtors and its loan period, in other words, the preference of debtors to donors. Judging from loan amount, at present, the bank loan must be the most favorite for the handicraft householder who is a debtor because of its longest loan period. Loan from their relatives, however, still play important part as loan donors for handicraft households. For example, a handicraft household in Ninh Hiep procured a bigger amount of capital than another household borrowed from a bank. This example shows undeveloped banking system and weak financial capacity of bank in rural Vietnam, where the informal finance still plays a considerably important role for capital supply.

Table 7. Capital procurement by loan at the surveyed handicraft households

(Unit: Million dong; month)

\begin{tabular}{|c|c|c|c|c|c|c|c|c|}
\hline & \multicolumn{2}{|c|}{ Bat Trang } & \multicolumn{2}{|c|}{ Dai Bai } & \multicolumn{2}{|c|}{ Ninh Hiep } & \multicolumn{2}{|c|}{ Long Van } \\
\hline & $\begin{array}{l}\vec{a} \\
\stackrel{\vec{a}}{a}\end{array}$ & 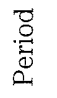 & 蒿 & 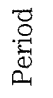 & 苛 & 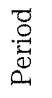 & $\stackrel{\overrightarrow{0}}{\stackrel{\leftrightarrow}{a}}$ & $\begin{array}{l}\overrightarrow{0} \\
\stackrel{0}{0} \\
0\end{array}$ \\
\hline 1. Loan from bank & 90 & 28 & 100 & 24 & 500 & 36 & 0 & - \\
\hline 2. Loan from private money lending & 10 & 12 & 25 & 12 & 200 & 12 & 0 & - \\
\hline 3. Loan from relatives & 40 & 24 & 30 & 24 & 600 & 24 & 0 & - \\
\hline 4. Loan from other source & 0 & - & 25 & - & 0 & - & 0 & - \\
\hline
\end{tabular}

Source: same as Table 2

Note: Dept shows the amount of loan by the household who borrowed most money among the surveyed households by creditor in each village.

\section{Distribution channels of the handicraft products}

Table 8 tells us the marketing of handicraft products. Looking at types of markets for handicraft products in each village, the products in Bat Trang were shipped for each market with the ratio of $25.9 \%$ for local markets, $48.2 \%$ for domestic urban markets, and $33.9 \%$ for foreign markets, respectively. In the same way, the products in Dai Bai were $22.2 \%, 77.6 \%$, and $0.4 \%$, that of Ninh Hiep was $43.6 \%, 49.2 \%$, and $7.1 \%$, and that of Long Van was $19.1 \%, 80.9 \%$, and $0 \%$. As these figures indicate, the main market for traditional handicraft products was domestic ones, especially in urban areas, which have a bigger and stable demand. Another characteristic is that the demand for the traditional herb medicine of Ninh Hiep in rural area is as high as urban areas. The high-age or lower income groups, who live mainly in the rural areas, prefer to use reasonable traditional herb medicine so that there is an extent of demand for that product in rural areas. And other remarkable fact is that the products in Bat Trang exported to foreign countries were over $30 \%$ of total products. It means foreign markets have become main market as well as domestic markets for the products. Besides, $7 \%$ of traditional medicine in Ninh Hiep was 
also exported to foreign market, especially in China.

Observing the distribution route of those products, it is clear that most products in Bat Trang and Ninh Hiep were sold through distributors. In these villages, specialized distributors have established their business status and some of them have successfully developed their business to become big-size commission agent. Such tendency must be more and more remarkable in near future. ${ }^{6}$

Table 8. Market diversification and distribution route of the products in handicraft villages

(Unit: \%)

\begin{tabular}{lcrrr}
\hline & Bat Trang & Dai Bai & Ninh Hiep & Long Van \\
\hline 1. Types of market of the handicraft products & & & & \\
- Domestic rural market & 25.9 & 22.2 & 43.6 & 19.1 \\
- Domestic urban market & 48.2 & 77.6 & 49.2 & 80.9 \\
- Foreign market & 33.9 & 0.4 & 7.1 & - \\
2. Distribution route of the products & & & & \\
- Direct marketing by producers & 8.7 & 35.2 & 13.9 & 40.6 \\
- Marketing through distributors & 91.3 & 64.8 & 86.1 & 59.4 \\
\hline
\end{tabular}

Source: same as Table 2

\section{Profitability of handicraft business}

Table 9 tells us the economic performance of the handicraft production households. The average total gross income of surveyed households in 1998 was 46.4 billions dong in Bat Trang, 45.7 billions dong in Dai Bai, 190.5 billions dong in Ninh Hiep, and 2 billions dong in Long Van. Whereas the net income of them was as follows: 6.4 billions dong in Bat Trang; 3.9 billions dong in Dai Bai; 25.5 billions dong in Ninh Hiep; 9 millions dong in Long Van, respectively. As far as these figures indicate, the profitability of handicraft household is very much higher than that of any rural households those have no handicraft business. Especially, the profitability of the households in Ninh Hiep was extremely huge. Then, analyzing the profitability by handicraft and agricultural sector, the following facts were obtained by each village.

(1) The gross income of the handicraft sector in Bat Trang was 46.2 billions dong, which occupied almost $100 \%$ of the total gross income. The gross income of handicraft sector was mainly generated from fine art products and it reflected the characteristics depending on foreign markets as mentioned above. The net income of handicraft sector was 6.4 billions dong and its income ratio was $13.8 \%$. The agricultural gross income and net income were only 1.4 millions dong and 20 thousands dong, respectively. Its income ratio was only $1.4 \%$.

6 In Bat Trang, a remarkable structural change can be observed. Some big private and joint export companies have been established and small-scale producers are integrated into their control. And small-scale producers intend to change their business from production to sales because the profitability of distributors is fully over that of ceramic producers, recently (Mai, 2000). 
(2) The gross income of the handicraft sector in Dai Bai was 45.1 billions dong that came up to almost $100 \%$ of the total gross income as same as the case of Bat Trang. The gross income of handicraft sector was mainly from household appliances. The net income of handicraft sector and the income ratio were 5.6 billions dong and $12.4 \%$, respectively. Although the gross income of the agricultural sector was 5.4 millions, the net income was complete deficit.

(3) The gross income of the handicraft sector in Ninh Hiep was 67.4 billions dong, which covered $35.4 \%$ of the total gross income. The net income of the handicraft sector and the net income ratio were 20.5 billions dong and $30.4 \%$, respectively. The gross income and the net income of the agricultural sector were 123.1 billions dong and 5 billions dong, respectively. Its income ratio was only $4.1 \%$.

(4) The gross income of the handicraft sector in Long Van was 4.2 millions dong that occupied $21.7 \%$ of the total gross income. The net income and the net income ratio of the handicraft sector was 3 millions dong and $69.9 \%$, respectively. The gross income and the net income of the agricultural sector were 15 millions dong and 6 millions dong, respectively. Its net income ratio was $40.0 \%$.

The followings remarks are brought from the said facts.

(1) The economic structure of handicraft households in Bat Trang and Dai Bai is almost similar each other. The net income ratio of the handicraft in both villages is rather low because of the high capital composition as mentioned above. Further more, the economic status of agricultural sector for the handicraft households in both villages is already purposeless. Apart from Bat Trang with only nine ha of cultivated land, it must be necessary, in Dai Bai where still there is a lot of agricultural land, to make up

Table 9. Profitability at the surveyed household

(Unit: Thousand dong)

\begin{tabular}{lrrrr}
\hline & Bat Trang & Dai Bai & Ninh Hiep & Long Van \\
\hline 1. Whole business & & & & \\
- Total gross income & 463,559 & 456,649 & $1,905,049$ & 19,665 \\
- Total expenses & 399,929 & 417,170 & $1,650,002$ & 10,524 \\
- Total net income & 63,630 & 39,479 & 255,047 & 9,141 \\
- Net income ratio (\%) & 13.7 & 8.6 & 13.4 & 46.5 \\
(of which) & & & & \\
2. Handicraft sector & & & & \\
- Gross income & 462,157 & 451,243 & 674,030 & 4,258 \\
$\quad$ +From fine art products (\%) & 67.3 & 45.1 & 0.0 & 0.0 \\
$\quad$ +From household appliances (\%) & 32.7 & 54.9 & 100.0 & 100.0 \\
- Expenses & 398,547 & 395,071 & 469,135 & 1,281 \\
- Net income & 63,610 & 56,172 & 204,895 & 2,977 \\
- Net income ratio (\%) & 13.8 & 12.4 & 30.4 & 69.9 \\
3. Agricultural sector & & & & $1,231,019$ \\
- Gross income & 1,402 & 5,406 & 1,407 \\
- Expenses & 1,382 & 22,099 & $1,180,867$ & 9,243 \\
- Net income & 20 & $\triangle 16,693$ & 50,152 & 6,164 \\
- Net income ratio (\%) & 1.4 & - & 4.1 & 40.0 \\
\hline
\end{tabular}

Source: same as Table 2 
efficient countermeasures for maintaining its regional agriculture as quickly as possible.

(2) In Ninh Hiep where the agriculture has close interrelation with the handicraft sector as the materials supplier, the status of agricultural sector for the handicraft household is much different from the two villages of Bat Trang and Dai Bai. The net income of the agricultural sector accounts for about $20 \%$ of the total net income. However, the net income ratio of agriculture is just only $4.1 \%$ and its efficiency is incredibly low. Nevertheless a tremendous gross income of agricultural sector, its net income cannot stand comparison with that of the handicraft sector. Therefore, the improvement of the efficiency of agricultural sector is a pressing problem by which the handicraft households and the local government are confronted.

(3) In Long Van, the situation is completely different comparing to the other three villages. For the handicraft households in Long Van, the handicraft business stands as a supplemental sector of the household economy. The higher net income ratio of the handicraft business is caused by family labor use without any employees and only simple equipment for production. Then, the agricultural sector is more important for the household economy in Long Van. The net income of agricultural sector occupies $67.4 \%$ of the total net income. In short, the handicraft households in Long Van kept a balance between their handicraft and agricultural sector with the trade-off for a dynamic development of the handicraft sector.

\section{DISCUSSION}

\section{Development factors of the handicraft business}

From the research results in the previous section, the main development factors of handicraft villages in Kinh Bac can be summarized as follows:

(1) Extremely high population in this area enabled to supply much inexpensive and painstaking labor force for the labor-intensive traditional handicraft production;

(2) Each handicraft producer maintained unique production skills and professional knowledge, and made their products differentiate from their followers;

(3) The handicraft producers could enjoy huge demand for their product with big urban

Table 10. Favorable factors for the development of handicraft business

(Unit: \%)

\begin{tabular}{|c|c|c|c|c|c|c|c|c|c|}
\hline Evaluation & 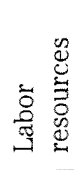 & 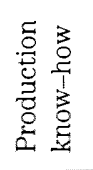 & 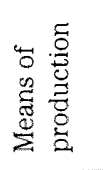 & $\begin{array}{l}\text { 芯 } \\
\text { 芯 }\end{array}$ & 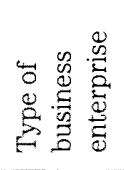 & 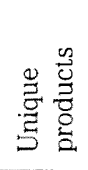 & 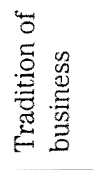 & $\frac{\overrightarrow{0}}{\frac{0}{2}}$ & 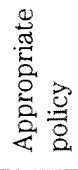 \\
\hline Poșitive & $\underline{48.3}$ & $\underline{35.5}$ & 24.8 & 30.1 & 23.4 & 37.6 & $\underline{58.4}$ & 63.7 & 12.7 \\
\hline Fair & 12.1 & 18.1 & 13.5 & 18.2 & 18.8 & 12.0 & 40.2 & 13.5 & 30.3 \\
\hline Negative & 36.3 & $\underline{46.3}$ & 61.8 & $\underline{51.6}$ & 57.8 & 50.3 & 0.0 & 22.8 & 57.0 \\
\hline
\end{tabular}

Source: same as Table 2 
markets such as Hanoi nearby.

Table 10, which shows the views of the handicraft householders on their business development, serves as evidence of the said statement. The handicraft householders considered "Market", "Tradition of business", "Labor resources" as favorable factors for their business development followed by "Unique products" and "Production know-how".

\section{Structural changes in the handicraft business and constraints for the sustain- able development}

On the other hand, the same Table 10 indicates some noncontributory factors for the past development such as "Means of production", "Types of business enterprise", "Appropriate policy", "Capital" etc. Then, of the said noncontributory factors, Table 11 shows thrustful disincentives for the further development of small-scale handicraft business. The handicraft producers are especially afraid of "Less competitive power", "Capital shortage", and "Material shortage" of their business. This fact explains the competition between the small-scale handicraft producers and new entry of the large-scale companies with the advanced facilities and a big amount of capital in the current structural changes of the handicraft sector or villages. In short, the attainment of mass-production of handicraft products makes the advantages of the traditional small-scale producers in production skill out-of date and brings the small-scale handicraft business to a severe competition in procurement of raw materials.

Table 11. Constraints on the further development of handicraft business

\begin{tabular}{lcccccc} 
& \multicolumn{1}{c}{} & & & (Unit: \%) \\
\hline Evaluation & $\begin{array}{c}\text { Backward } \\
\text { means of } \\
\text { production }\end{array}$ & $\begin{array}{c}\text { Less } \\
\text { developed } \\
\text { business } \\
\text { enterprise }\end{array}$ & $\begin{array}{c}\text { Less } \\
\text { government } \\
\text { al support }\end{array}$ & $\begin{array}{c}\text { Capital } \\
\text { shortage }\end{array}$ & $\begin{array}{c}\text { Less } \\
\text { competitive } \\
\text { power }\end{array}$ & $\begin{array}{c}\text { Material } \\
\text { shortage }\end{array}$ \\
\hline Serious & 19.5 & 29.5 & 30.2 & $\underline{54.4}$ & $\underline{55.1}$ & $\underline{11.6}$ \\
Difficult & 28.2 & 14.8 & 25.5 & 13.4 & $\underline{31.6}$ \\
Easy & 52.3 & 55.7 & 44.3 & 32.3 & 33.6 & 41.6 \\
\hline
\end{tabular}

Source: same as Table 2

Concerned with the sustainable development of handicraft business, another critical issue is environmental conservation in the handicraft villages. As touched in the previous section, environmental pollution has already become a serious problem, which is ready to affect to human body in some handicraft villages. Of course, the level of contamination is different based on kind of products and processing technology. Recently, Nylon reprocessing, metal manufacturing, ceramics production, and agricultural product processing are the most serious environmental pollution sources. However, there are still no regulations to control the pollutants that such industries discharge. Some governmental action is required to call producer's attention to the environment and human health. 


\section{CONCLUSION}

\section{Conclusions of the paper}

For the conclusions, on the basis of the three subjects of the study described at the beginning of this paper, let us summarize several observations in the former chapters.

(1) First, it was clear that the development of handicraft households, in general, contributes to creating job opportunities for not only the household members but also hired workers and improving the household income. And, the development of handicraft business helped to establish other related job opportunities such as transportation and sales in the region. However, the employment capability was rather different depending on the kind of products, and the business size and intensity of each enterprise.

(2) Secondly, as a trial for breaking out the limitations of family handicraft business such as capital shortage and low technology, the establishment of new types of business organization such as limited company or joint enterprise was observed. Under the development of such new types of business organization, the differences in the size and intensity among handicraft enterprises are enlarging more and more, and it has been remarkable that only a few numbers of large companies are growing very rapidly.

(3) Thirdly, in the villages with the highly developed handicraft sector, it was observed that the status of agricultural sector in the individual handicraft households made a backward and the regional agriculture was destroyed or is on the way to destruction. Of course, the development of handicraft sector cannot be regarded as the prime factor of this problem. The point to be cared is its development planning.

\section{Some comments for the following researches}

In the previous sections, although the significance of the traditional rural handicraft industry in Vietnam, especially in the Red River Delta, has been pointed out, the number of researches on it from the angle of agricultural economics or farm management is still limited. Even due to our research, many subjects to be studied after this became clear. Then, we would like to point out only five important subjects to be focused in the field of agricultural economics.

(1) The study on the management of the handicraft enterprises: Especially, this study should be conducted on the advanced business enterprises which have many management problems such as production management, hired-labor management, material management, marketing management, and financial management and so on. Its management process is more complicated than that of family enterprise. Therefore, the contribution of scientific research is required.

(2) The study on the competition and cooperation among the individual handicraft producers: It is the problem of this study to make clear the way for pursuing the benefit in both market economy and organization. For example, in order to solve material shortage problem in Bat Trang, it might not be correct to fully follow the competition among producers. We should try to find out the most adequate way of competition and cooperation.

(3) The study on the management of regional agriculture: Under the rapid development 
of rural handicraft industry, the efficient methods to manage the regional agriculture getting extensive are necessary. For this purpose, it might be useful to learn the experience of group farming in Japan.

(4) The study on the rural planning: Even if handicraft sector develops rapidly, the degeneration of agriculture sector is not inevitable. In other words, it is important to reasonably place the development plan of handicraft sector and agricultural sector in rural development plan as a whole. It is necessary that this study be conducted depending on the useful theory in the field of rural planning.

(5) The study on the management of rural environment: In the following researches, it is required to make clear the effective methods to manage the local environment in the rural Vietnam.

\section{ACKNOWLEGEMENTS}

This paper is a part of results in the joint research between authors supported in part by a grant from HAU-JICA ERCB project. This research owes much to the helpful comments of Prof. Dr. Kenji Cho, who is the former chief advisor of HAU-JICA ERCB project. And, the authors thank Mr. Dinh Van Hien and Ms. Nguyen Phuong Le, who were the collaborators in this research.

\section{REFERENCES}

CHO, K. 2000 Comments on the studies of traditional handicraft and handeraft villages. In "Rural Economy Development Issues in the Red River Delta", Proceedings of the $4^{\text {th }}$ joint workshop at HAU-JICA ERCB Project, ed. by Hanoi Agricultural University (HAU) and HAU-JICA ERCB Project office, HAU, Hanoi, Vietnam, pp 73-74.

Dinh, P. V. 2000 Issues on the development of traditional handicraft villages in the ancient land of Kinh Bac. In "Rural Economy Development Issues in the Red River Delta", Proceedings of the $4^{\text {in }}$ joint workshop at HAU-JICA ERCB Project, ed. by HAU and HAU-JICA ERCB Project office, HAU, Hanoi, Vietnam, pp $49-57$.

Hien, D. V. 2000 Measures to preserve and develop Ninh Hiep traditional handicraft village. In "Rural Economy Development Issues in the Red River Delta", Proceedings of the $4^{\text {th }}$ joint workshop at HAU-JICA ERCB Project, ed. by HAU and HAU-JICA ERCB Project office, HAU, Hanoi, Vietnam, pp $59-66$.

Mai, P. V. 2000 History and current situations of Bat Trang traditional village: Ceramics production and environmental pollution. In "Rural Economy Development Issues in the Red River Delta", Proceedings of the $4^{\text {th }}$ joint workshop at HAU-JICA ERCB Project, ed. by HAU and HAU-JICA ERCB Project office, HAU, Hanoi, Vietnam HAU, Hanoi, Vietnam, pp 67-71.

Note: This paper extends and enlarges upon the ideas and materials in Dinh (2000) through the discussion with Pham Van Dinh. 